\title{
COLLABORATION IN PEDIATRIC SURGICAL TRAINING \& EDUCATION AMONG ASIAN COUNTRIES \& BEYOND -BANGLADESH PERSPECTIVE
}

Bangladesh is one of the most densely populated countries \& while still a developing economy, has significant improvements in health and social development. Per capita income was only US $\$ 78$ in 1972-just after independence which is now reached US\$ 1044 and Bangladesh is now going to enter into middle income country! Though agriculture, garments industry \& remittance have played a major role in economy it has been at the forefront of several advances in development and health. Oral Rehydration Solution (ORS) was developed and popularized in Bangladesh. It has been credited with saving 40 million lives worldwide. Bangladesh is on the right track in achieving millennium development goals \& due to reduction of under five mortality rate Hon'ble Prime Minister Sheikh Hasina has received MDG 4 award from the United Nations in 2010. The micro-credit movement pioneered by Grameen Bank and Nobel laureate Professor Yunus is now a global phenomenon and also directly resulted in improvement of health care at the grass-root level.

In Bangladesh Pediatric Surgery started its journey from late nineteen seventies after establishing the Dhaka Children Hospital \& later 5 years masters program was started under University of Dhaka. In 2002, Bangladesh Medical and Dental Council included Pediatric Surgery in MBBS course curriculum. As a result, graduate medical students are now able to gain theoretical as well as practical knowledge about common pediatric surgical problems. After the active initiative of Association of Pediatric Surgeons of Bangladesh(APSB) in the new 2013 MBBS curriculum BMDC has given the right importance to the common surgical problems of about $50 \%$ population of the country that is the children \& to make the students more competent doctors for the first time included 2 weeks ward placement of $5^{\text {th }}$ year students including 15 hours lecture in the new curriculum.

In the time of globalization with rapid technological advancement we need collaboration in education \& training especially among Asian countries so that we can provide the best possible treatment for our future generation. Presently we have collaboration in pediatric surgical education \& training with Singapore \& Japan. Professor Anette S. Jacobsen is providing training in her K.K. Women \& Children Hospital. Last year we have celebrated the 40 years of Japan Bangladesh friendship 1972-2012 \& Professor Akio Kubota, a very good friend of Bangladesh, is also providing education \& training for the pediatric surgeons of Bangladesh in Osaka Medial Centre for Maternal \& Child Health. With his support APSB now make this program institutionalize \& more effective by incorporating it in Japan International Cooperation Agency's (JICA) training program. In one year JICA will provide training for 20 pediatric surgeons from Bangladesh. Gradually these collaboration should be broaden \& more countries should be included.

Likewise young pediatric surgeons/trainees from other countries can come to Bangladesh \& have some training program with the abundance of varieties of patients including congenital anomalies. Some of Bangladeshi pediatric surgeons have trained in Children's Hospital Boston, teaching hospital of Harvard Medical School \& also Faimer Institute Fellows of Philadelphia (Faimer.org) on medical education and some from Australia, UK but it will be more practical and effective to improve 
collaboration in education \& training among Asian countries. We hope the resource rich Asian countries will come forward to implement this idea into reality.

The children are one special category of human being. One must realize that on their growth lies not only the future but also the growth of the future. Therefore, they require special care \& treatment. Our future shall depend on the future of our children. To ensure effective and sustainable improvement of child health and maternal health and to achieve MDG health professionals, politicians, public servants, private sectors along with UNICEF, WHO, should work together. Everyone must mind this what poet Gabriela Mistral (Nobel laureate from Chile) has said-

We are guilty of many errors and many faults but our worst crime is abandoning the children neglecting the fountain of life.

Many of the things we need can wait.

The child cannot,
Right now is the time his bones are being formed his blood is being made and his senses are being developed To him we cannot answer 'Tomorrow' His name is 'Today'.

Author presented this talk as invited speaker in the $50^{\text {th }}$ Annual Meeting of Japanese Society of Pediatric Surgeons in June 1, 2013 in Tokyo. email: ahaniftablu@hotmail.com; cell: 8801715160371.

\section{Dr. Abdul Hanif (Tablu)}

MBBS, MS (Pediatric Surgery), MMEd, Faimer Institute Fellow 2010, USA

Associate Professor, Department of Pediatric Surgery, Dhaka Medical College, Bangladesh \& Joint Secretary, Association of Pediatric Surgeons of Bangladesh.

email: ahaniftablu@hotmail.com 